\title{
Polish and Finnish nursing students' attitudes, knowledge and skills related to research utilisation
}

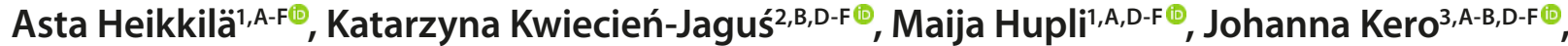 \\ Jouko Katajisto ${ }^{4, C-D, F}$, Leena Salminen ${ }^{1, A, D-F} \oplus$, Helena Leino-Kilpi ${ }^{1,5, A, D-F} \oplus$ \\ ${ }^{1}$ Department of Nursing Science, University of Turku, Finland \\ ${ }^{2}$ Department of General Nursing, Medical University of Gdańsk, Poland \\ ${ }^{3}$ Welfare and Health, Satakunta University of Applied Sciences, Finland \\ ${ }^{4}$ Department of Mathematics and Statistics, University of Turku, Finland \\ ${ }^{5}$ Turku University Hospital, Turku, Finland \\ A - Koncepcja i projekt badania, B - Gromadzenie i/lub zestawianie danych, C - Analiza i interpretacja danych, \\ D - Napisanie artykułu, E - Krytyczne zrecenzowanie artykułu, F - Zatwierdzenie ostatecznej wersji artykułu
}

Heikkilä A, Kwiecień-Jaguś K, Hupli M, Kero J, Katajisto J, Salminen L, Leino-Kilpi H. Polish and Finnish nursing students' attitudes, knowledge and skills related to research utilisation. Med Og Nauk Zdr. 2019; 25(3): 181-186. doi: 10.26444/monz/111726

\begin{abstract}
Introduction. Evidence-based practice and research utilisation at its core are essential for high quality patient care. In this study, research utilization is defined as a process involving acquisition, critical reading (including evaluation) and application of research knowledge. The translation of research knowledge into clinical nursing practice, however, is often hampered, primarily due to nurses' lacking competence for research utilization.

Objective. The aim of this study is to assess and compare graduating nursing students' attitudes, knowledge and skills related to research utilisation in two European countries.

Materials and method. Data was collected in Poland $(n=168)$ and Finland $(n=260)$ using the Competence in Research Utilisation instrument, and analysed statistically.

Results. Students in both countries had positive attitudes to research utilisation. Polish students' attitudes were more positive. A knowledge test revealed poor knowledge of research utilisation in both countries. Students assessed their research utilisation skills as above moderate, but Polish students rated their skills higher.

Conclusions. Based on the results, students' skills cannot be regarded as moderate or good, since they lack a solid theoretical knowledge base. Further development of curriculum content and a search for effective pedagogical methods for classroom, clinical and digital settings are recommended to support the students' learning of research utilization. In the future, multidimensional, international competence assessments are recommended.
\end{abstract}

\section{Key words}

attitude, evidence-based practice, knowledge, nursing education, skills, students

\section{INTRODUCTION}

The importance of evidence-based practice in nursing has grown internationally in the past decades. In evidence based practice, decisions are based on the best available research evidence, patients' views, health professionals' expertise and the organization's resources. These are combined to support citizens' health and empowerment, and ensure high quality patient care. [1] Research utilisation (RU), one of the key competences to be achieved during nursing education $[2,3]$, is considered to be a core component of evidence based practice $[4,5]$. In this study, RU is defined as a process involving acquisition, critical reading (including evaluation) and application of research knowledge $[4,6]$. The translation of research knowledge into clinical nursing practice, however, is often hampered, primarily due to nurses' lacking competence for $\mathrm{RU}[7,8]$.

\footnotetext{
Address for correspondence: Asta Heikkilä, University of Turku, Department of Nursing Science, Finland

E-mail: asta.heikkila@utu.fi

Received: 4 June 2019; Accepted: 12 August 2019; First published: 11.09.2019
}

Although RU has been studied worldwide $[9,10,11,12]$, there is still limited research on nurses', and especially on nursing students' attitudes, knowledge and skills related to RU. The existing research has mostly dealt with factors which hinder or promote RU $[7,13]$, or RU has been discussed in the context of evidence based practice teaching experiments $[9,14]$. Few studies have focused solely on the assessment of student's RU competence $[12,15,16]$ although such evidence is necessary to identify appropriate strategies to improve RU education and the application of research findings into nursing practice [9].

The existing research on nursing students' RU has found that students' attitudes are mainly positive $[9,16]$. Students believe that research is important for nursing practice, for the quality of patient care [9] and for the development of the profession, and they agree that nurses should learn to read, evaluate and utilise research findings in practice [11]. Nursing students' RU knowledge and skills, however, have frequently been shown to vary from low to moderate, whether based on tests or self-assessment $[12,17,18]$. Evidence shows that nursing students have limited skills in formulating questions to search for research knowledge, in carrying out database searches, and in critically appraising and implementing 
research results $[15,18]$. Students also find research daunting, or difficult to read and understand [11]. The majority of the nursing research has been published in English, which is a further challenge for students in non-English speaking countries [19].

In summary, the results on nursing students' RU attitudes, knowledge and skills have remained relatively constant over time and across geographical locations. Recent research has primarily concentrated on testing evidence based practice teaching activities cross-sectionally immediately after the courses from the point of view of students [9] or faculty [20], mainly using limited sample sizes. Most results are not directly comparable because of different concepts, research designs, and measurement tools. There is also a lack of studies on the assessments of nursing students' RU learning outcomes at graduation. Finally, there is a shortage of international comparative assessments designed to investigate whether equal RU competences are reached in nursing education, as stipulated in the EU Directive 55 [2].

The present study is a part of a larger collaboration research project concerning RU competence among nursing students and nurses in three European countries, and presents the results regarding nursing students' RU attitudes, knowledge and skills in Poland and Finland. As there are some differences in nursing education between the two countries, it was of interest to investigate if the differences are reflected in nursing students' RU competence. Poland represents a European country in which the reform of higher education was launched somewhat later than in Finland [21]. The length of the Bachelor-level nursing education programme is 3 years in Poland and 3.5 years in Finland. In Poland, nursing studies are practically oriented [22]. RU is not yet widely known [9] as a separate subject, but the curricula include some scientific nursing research studies [23]. Some RU contents are discussed in the context of clinical courses, for example, when students learn surgical or diabetes nursing. In Finland, RU can be taught as separate courses or integrated into other courses and clinical training. Since the mid-2000's, there has been increased RU studies across the nursing curricula $[24,25]$.

\section{OBJECTIVES}

The aim of this study was to assess and compare graduating nursing students' attitudes, knowledge and skills related to RU in two European countries.

\section{MATERIALS AND METHOD}

A descriptive, cross-sectional study design was used with two groups of graduating nursing students from Poland and Finland, respectively. The inclusion criteria for the study participants were: being a full-time or part-time Bachelor level student, and in the last semester just prior to graduation. In Poland, convenience sampling was used in 2014. Invitations were sent to 14 universities situated in the bigest cities. Four universities agreed to participate. All graduating full-time and part-time nursing students of the universities were invited to participate. In Finland, in 2012, three universities of applied sciences were chosen from five university hospital district cities through random sampling. All graduating full-time nursing students were invited to participate. Participants were 168 graduating nursing students in Poland and 260 students in Finland. Demographic data are presented in Table 1.

Table 1. Finnish and Polish graduating nursing students' background information

\begin{tabular}{|c|c|c|c|c|c|c|c|c|c|c|c|}
\hline \multirow[t]{2}{*}{ Background variables } & \multicolumn{5}{|c|}{$\begin{array}{l}\text { Finnish cohort } \\
(n=259-260)\end{array}$} & \multicolumn{5}{|c|}{$\begin{array}{l}\text { Polish cohort } \\
(n=164-168)\end{array}$} & \multirow{2}{*}{$\begin{array}{l}\text { Differences of the groups } \\
\text { between the cohorts } \\
\text { p value }\end{array}$} \\
\hline & $\mathrm{n}$ & $\%$ & Mean & SD & Range & $\mathrm{n}$ & $\%$ & Mean & SD & Range & \\
\hline Gender & & & & & & & & & & & $0.008^{b}$ \\
\hline Women & 252 & 97 & & & & 150 & 91 & & & & \\
\hline \multicolumn{12}{|l|}{ University (of applied sciences) ${ }^{1}$} \\
\hline A & 95 & 37 & & & & & & & & & \\
\hline B & 29 & 11 & & & & & & & & & \\
\hline $\mathrm{C}$ & 135 & 52 & & & & & & & & & \\
\hline $\mathrm{D}$ & & & & & & 89 & 54 & & & & \\
\hline $\mathrm{F}$ & & & & & & 34 & 20 & & & & \\
\hline G & & & & & & 33 & 20 & & & & \\
\hline Prior vocational qualification in health care & & & & & & & & & & & $0.474^{\mathrm{b}}$ \\
\hline Yes & 49 & 19 & & & & 35 & 21 & & & & \\
\hline No & 211 & 81 & & & & 129 & 79 & & & & \\
\hline Working experience in health care & & & & & & & & & & & $<0.001^{b}$ \\
\hline Yes & 228 & 88 & & & & 53 & 32 & & & & \\
\hline No & 32 & 12 & & & & 115 & 68 & & & & \\
\hline \multirow[t]{2}{*}{ The length of working experience in health care (years) } & & & & & & & & & & & $<0.001^{\mathrm{b}}$ \\
\hline & & & 1.8 & 2.4 & $0.1-23$ & & & 4.43 & 8.55 & $0.3-32$ & \\
\hline
\end{tabular}

${ }^{1} \mathrm{~A}-\mathrm{G}=$ Code for the University (of applied sciences), SD $=$ Standard Deviation, ${ }^{\mathrm{a}}=$ Two-Samples T-Test,${ }^{\mathrm{b}}=$ Chi Square tests 
Instrumentation. Data was collected using the Competence in Research Utilisation (CompRU) instrument developed in Finland $[6,12]$. A back-translation of the CompRU instrument was used in Poland [26]. The translation process was repeated until the research group and translators agreed that an acceptable equivalence between original and target languages had been reached. The instrument consisted of 63 items within three sections: Attitudes to RU, Knowledge related to RU, and Skills related to RU. These sections had been divided into eight categories and nine sub-categories. Students' attitudes (16 variables) and skills (16 variables) were measured using a five-point Likert scale. In addition, students' knowledge was assessed by a knowledge test (31 variables). The test included four multiple-choice questions and 27 assignments, and scored by allocating one point for each correct answer.

The content validity of the instrument was evaluated in Finland by experts and students in nursing education, nurse teacher education and clinical practice in $2005(n=29)$, and retested in $2012(n=6)$. The Polish version was pretested in 2014 for clarity, comprehensiveness and appropriateness by newly graduated nurses $(n=9)$ in Poland. The instrument was found to be linguistically clear and understandable, therefore no amendments were made. Cronbach's $\alpha$-coefficient, used to test the consistency of the instrument, gave satisfactory values (Finland: 0.78-0.88, Poland: 0.80-0.90) in the RU attitudes and RU skills sections [27]. Construct validity was measured using principal component analysis. In both cohorts, the principal component analysis explained $46 \%$ (RU attitudes) and $63 \%$ (RU skills) of the variance of the data, indicating support for the theoretically formed categories.

Data collection. Data was collected just prior to the students' graduation. In Poland, the participants received the instructions in writing and orally from a researcher (in two universities) or a contact person (in the other two universities). Since it was not possible to use computers, the participants completed a paper questionnaire during a lesson. The completed forms were delivered to Finland for data analysis. In Finland, instructions were sent to contact persons in universities of applied sciences, who forwarded the covering letter and link to the questionnaire to the participants by email. Participants responded to the questionnaire during a class. The participants had to answer each question to be able to proceed to the next item.

Data analysis. The data analysis was based on descriptive statistics and statistical tests conducted by SPSS Version 22.0 software. Sum variables were formed according to theoretical categories and their reliability confirmed by calculating Cronbach's alpha coefficients, and by examining the compatibility of single questions with the instrument through item analysis. In addition, a principal component analysis (Promax with Kaiser rotation, eigenvalues over one as a criteria) was used to assess the theoretical construct of the instrument within the sections Attitudes to RU and Skills related to RU. The sample size was large enough (Central limit theorem) to use parametric tests without concerns of normality assumptions. The distributions were skewed to the same direction in the Finnish and Polish groups. Differences in background variables between cohorts were tested using Chi Square tests and the Two-Sample T-test (age), and Multifactor Analyses of Variance and the Binary Logistic Regression Model (clinical relevance) were employed to compare the mean scores of the two cohorts, with analysis adjusted by background variables. Significance levels of $<0.05$ were considered to be statistically significant.

Ethical considerations. Ethical principles were followed throughout the study [28]. The study protocol was approved by the Ethics Committee of the University of Turku, Finland (10/2012). In addition, permission for data collection was obtained according to the practices of each participating country and institution. Permission to translate the CompRU instrument was received from the copyright holder. Participants were asked for their signed informed consent on the first page of the questionnaire. Participation was voluntary and anonymous, and students could not be identified from the data.

\section{RESULTS}

Attitudes to research utilization. Students' attitudes to RU were measured with 16 items divided into two categories: Appreciation of RU and Commitment to RU. In both cohorts, nursing students' self-assessed attitudes to RU were rather positive, although Polish students had more positive attitudes compared to Finnish students $(\mathrm{p}<0.001)$. There were no differences in Polish or Finnish students' appreciation of $\mathrm{RU}$, but in both groups, appreciation was found to be higher than commitment to RU. It was also discovered that the commitment to RU was higher in Polish students compared to Finnish students $(\mathrm{p}<0.001)$. (Tab. 2).

Knowledge related to research utilization. Students' knowledge of RU was assessed by a knowledge test which

Table 2. Finnish and Polish graduating nursing students' self-reported attitudes and skills in research utilization

\begin{tabular}{|c|c|c|c|c|c|c|}
\hline \multirow{2}{*}{$\begin{array}{l}\text { Sections } \\
\text { Categories }\end{array}$} & \multirow{2}{*}{$\begin{array}{l}\text { Finnish students } \\
(n=260)\end{array}$} & \multirow{2}{*}{$\begin{array}{l}\text { Polish students } \\
(n=162-167)\end{array}$} & \multicolumn{4}{|c|}{ Comparisons of the groups ${ }^{a}$} \\
\hline & & & SE & $\mathrm{p}$ value & df & 95\% Cl for difference \\
\hline I Appreciation of research utilization & 4.33 & 4.35 & 0.07 & 0.745 & 1 & $-0.11,0.16$ \\
\hline /I Commitment to research utilization & 3.21 & 3.66 & 0.07 & $<0.001$ & 1 & $0.31,0.59$ \\
\hline Skills related to research utilization ${ }^{2}$ & 3.58 & 3.87 & 0.07 & $<0.001$ & 1 & $0.15,0.43$ \\
\hline I Acquisition of research knowledge & 3.53 & 3.83 & 0.09 & 0.001 & 1 & $0.13,0.48$ \\
\hline II Critical reading of research & 3.60 & 3.84 & 0.08 & 0.003 & 1 & $0.08,0.39$ \\
\hline III Application of research & 3.60 & 4.00 & 0.09 & $<0.001$ & 1 & $0.22,0.56$ \\
\hline
\end{tabular}

$\mathrm{SE}=$ Standard Error ${ }^{\mathrm{a}}=$ Multifactor Analysis of Variance

15-point Likert scale: $1=$ disagree completely; $2=$ disagree partially; $3=$ neither agree nor disagree; $4=$ agree partially $5=$ agree completely

25 -point Likert scale: $1=$ very poor; $2=$ rather poor; $3=$ neither well nor poorly (moderately); $4=$ rather well; $5=$ very well 
Table 3. Knowledge related to research utilization by Finnish and Polish graduating nursing students

\begin{tabular}{|c|c|c|c|c|c|c|}
\hline Section & Finnish students & Polish students & & Comp & the & \\
\hline Sub-categories & Correct answers & Correct answers & & & & \\
\hline & $\%$ & $\%$ & SE & $\mathrm{p}$ value & df & $95 \% \mathrm{Cl}$ for difference \\
\hline Knowledge related to research utilization' & 43.93 & 19.49 & 2.48 & $<0.001^{\mathrm{a}}$ & 1 & $-29.33,-19.55$ \\
\hline I Aquisition of research knowledge & 41.67 & 16.92 & 3.54 & $<0.001^{\mathrm{a}}$ & 1 & $-31.71,-17.78$ \\
\hline Information sources & 34.95 & 3.70 & 4.39 & $<0.001^{\mathrm{a}}$ & 1 & $-39.87,-22.63$ \\
\hline Methods of information acquisition & 48.40 & 30.14 & 4.76 & $<0.001^{\mathrm{a}}$ & 1 & $-27.62,-8.89$ \\
\hline II Process of producing research & 43.77 & 19.16 & 2.76 & $<0.001^{\mathrm{a}}$ & 1 & $-30.03,-19.18$ \\
\hline Structure of research articles & 64.19 & 26.27 & 4.26 & $<0.001^{\mathrm{a}}$ & 1 & $-46.30,-29.54$ \\
\hline Research terminology & 37.50 & 13.05 & 3.70 & $<0.001^{\mathrm{a}}$ & 1 & $-31.74,-17.17$ \\
\hline Research approaches & 34.40 & 22.45 & 4.80 & $0.013^{\mathrm{a}}$ & 1 & $-21.38,-2.53$ \\
\hline Data analysis methods & 32.87 & 22.71 & 3.84 & $0.008^{\mathrm{a}}$ & 1 & $-17.71,-2.62$ \\
\hline III Evaluation criteria for research & 47.14 & 23.95 & 4.08 & $<0.001^{\mathrm{a}}$ & 1 & $-31.21,-15.16$ \\
\hline Reliability & 46.17 & 18.39 & 4.24 & $<0.001^{\mathrm{a}}$ & 1 & $-36.12,-19.44$ \\
\hline Clinical relevance & 60.38 & 47.02 & -- & $0.179^{b}$ & -- & -- \\
\hline
\end{tabular}

$\mathrm{SE}=$ Standard Error of Difference; ${ }^{\mathrm{a}}=$ Multifactor Analysis of Variance; ${ }^{\mathrm{b}}=$ Binomic Logistic Regression Model ${ }^{*}=$ value replaced by means of other items in the test.

${ }^{1}$ Knowledge Test including multiple-choice questions and assignments (scoring: one point for a right answer).

included 31 items divided into three categories, and further into nine sub-categories. The knowledge test revealed poor knowledge of RU in both groups. Under $50 \%$ of the students gave correct answers to the test questions. Compared to Polish students, Finnish students' score was statistically significantly higher for the whole knowledge section $(\mathrm{p}<0.001)$ and for all knowledge categories except "Clinical relevance". Finnish students scored highest in the category "Structure of research articles", whereas Polish students had the highest scores in "Clinical relevance". The Polish students scored lowest in the categories "Information sources" and "Research terminology". In these categories, the difference to Finnish students was statistically significant $(\mathrm{p}<0.001)$. The Finnish students scored lowest in the categories "Data analysis methods" and "Research approaches", in which under $35 \%$ of the students gave the correct answer. (Tab. 3).

Skills related to research utilization. Students' RU skills were measured with 16 items divided into three categories: Acquisition of research knowledge, Critical reading of research, and Application of research. Students' self-assessed RU skills were above moderate in both groups for the whole skills section. In both the whole skills section $(\mathrm{p}<0.001)$ and in all three categories, Polish students assessed their skills higher than Finnish students. Both groups assessed their skills to be best in the categories "Application of research" and poorest in "Acquisition of research knowledge", but the difference between the categories was small in both groups. (Tab. 2).

\section{DISCUSSION}

The study, whose aim was to assess and compare nursing students' RU attitudes, knowledge and skills at graduation in two European countries - Poland and Finland - revealed mainly positive attitudes to RU attitudes in both countries.
Other studies have reported similar results [16]. The finding is encouraging because a positive attitude is a key factor underpinning the implementation of research into clinical practice, which in turn has been shown to influence patient safety and the quality of nursing care [13]. Polish students' attitudes were more positive, although RU has been promoted for nearly 20 years in Finland [6], while not yet widely known in Poland [10]. This finding might be attributed to a "charm of novelty" associated with RU in Poland. It was also discovered that in both countries, students' appreciation of RU was higher than their willingness to commit themselves to RU, possibly because research implementation was considered demanding [11]. The results call for further development and dissemination of research knowledge in a more condensed and usable form, for example, as systematic literature reviews or clinical practice guidelines summarizing and evaluating evidence on the care of various conditions to inform nurses clinical decisions [5].

The knowledge test revealed poor knowledge of RU in both groups. The results for Finnish students are reminiscent of those measured with the same instrument and reported by Heikkilä et al. [12], which indicates that there has been no clear progress in RU knowledge in Finland during the past decade. Similarly, in Poland, both Bachelor [10] and Master level [23] nursing students have been found to have insufficient RU knowledge. Other international studies $[17,18]$ have also revealed low to moderate levels of RU knowledge. Although both groups exhibited poor knowledge, Finnish students clearly scored higher in all knowledge categories. The reform of higher education was launched somewhat earlier in Finland than in Poland [21], indicating a longer history of research-based teaching and contents including separate RU courses. Hence, these facts might partially explain Finnish students' better RU knowledge. In contrast, the concept of RU is not yet extensively known in Poland [10] and RU is commonly integrated into other courses. 
Students' poor knowledge of RU is worrying because the knowledge test contained points essential for acquisition of research knowledge, critical reading and application of research. Good understanding of these topics promotes research-based clinical practice [4]. Encouragingly, however, most students in both groups were to some extent familiar with the structure of research articles, which is likely to be associated with their ability to read research. Few Polish students were familiar with the information sources asked, which may be due to students' limited access to the Internet [19]. Finally, since the research is mainly published in English, students' knowledge of research terminology was tested using English terms. Despite the reasonable good English language skills of Europeans [29], the results of this study indicate that the language barrier might still be a significant problem in both countries when specific research terminology is required.

Both Polish and Finnish students assessed their RU skills as above moderate. There were only minor differences between the countries, but Polish students' self-ratings were slightly higher. Self-rated nursing competence frequently ranges from moderate to good [3], but in this study it can be inferred from the knowledge test that students' RU skills were not moderate or good, despite their relatively high self-confidence. Other studies also found that nursing students perceived themselves as more information-literate than they actually were when tested, or that their self-reported knowledge of evidence based practice was higher than their objectively assessed knowledge [17]. It is possible that familiarization with the terminology used in the items, rather than a comprehensive understanding of RU, may have contributed to students' excessive self-confidence. It would seem that students need more opportunities to improve their self-assessment skills in RU.

In Finland, nationwide professional competence requirements including RU and evidence based practice, have recently been defined for nurses [25]. These requirements are being revised in 2019-2020 in a nationwide project supported and financed by the Ministry of Education and Culture [30]. Although the universities of applied sciences can autonomously decide their curricula, the adoption of the new competence requirements should be strongly advocated to achieve an increasingly unified education and better RU learning outcomes in Finland. Courses in RU can also be recommended for Poland in order to expand students' RU competence for future practice [23]. Nursing education in Poland could benefit from international cooperation, but also from Polish medical universities' good practices and research tradition [19].

The value of the results reported in this paper lies in the comparison between nursing students' RU attitudes, knowledge and skills with different histories of higher education and RU. There is a lack of comparative, crosscultural studies measuring learning outcomes on this topic. In the future, multidimensional, international competence assessments are recommended, including viewpoints of nurse teachers, clinical supervisors, nurse teacher educators and even patients. Joint nursing competence assessment is essential to ensure high-quality nursing care in the area of European Union $[2,3]$ and to identify appropriate strategies to improve RU education [9].

The study has some limitations. The first concerns the representativeness of the sample. Students were recruited from a limited number of settings and the sampling was conducted differently in Poland and Finland, which might have resulted in selection bias. Considering these limitations, all background variables were controlled for in statistical comparisons, so that the results for the cohorts became comparable. It is suggested that although the results cannot be generalised, the data gives an overview of nursing students' RU attitudes, knowledge and skills in the two countries. Second, during data analysis it was noticed that the Polish data included a translation and technical mistake in one category of the knowledge test. All three items in the category "Data collection methods" were replaced by means of other items in the test. The results of this category are not comparable between the two groups. The mistake also had a minor influence on the validity of the entire test results. However, as considering the students' poor knowledge levels, the mistake in one category is not likely to have influenced the results significantly.

\section{CONCLUSIONS}

The study provides evidence of nursing students' positive attitudes towards RU in Poland and Finland. Based on students' self-assessment and a knowledge test, nursing students' RU competence is poor as regards knowledge, but slightly above moderate as regards skills. In addition, clear differences were observed between the two countries. Regrettably, students' knowledge of RU seems insufficient for research-based nursing practice. It can be assumed that their skills are not moderate or good since they seem to lack a solid theoretical knowledge base.

Educational institutions have a significant role in promoting RU in nursing care. This study suggests that it is necessary in both countries to seek, study and further develop effective contents and pedagogical methods in classroom, clinical and digital settings to support the learning of RU. In the future, multidimensional, international competence assessments are recommended. It is also recommended that the RU competence of nurse educators should be tested, and further training provided as required.

\section{Acknowledgments}

The authors wish to thank dr hab. Wiolecie MędrzyckiejDąbrowskiej and dr hab. Aleksandrze GaworskiejKrzemińskiej for their support of the project.

\section{REFERENCES}

1.Melnyk BM, Gallagher-Ford L, Long LE, Fineout-Overholt E. The establishment of evidence-based practice competencies for practicing registered nurses and advanced practice nurses in real-world clinical settings: Proficiencies to improve healthcare quality, reliability, patient outcomes, and costs. Worldviews Evid Based Nurs. 2014; 1: 5-15.

2. European Union. Directive 2013/55/EU of the European Parliament and of the Council. Official journal of the European Union https://eur-lex. europa.eu/LexUriServ/LexUriServ.do?uri=OJ:L:2013:354:0132:0170:e n:PDF (accessed 29 May 2019).

3. Kajander-Unkuri S. Nurse Competence of Graduating Nursing Students. PhD Thesis, University of Turku, Finland, 2015.

4. Florczak KL. Evidence-Based Practice: What's New Is Old. Nurs Sci Q. 2016; 29: 108-112.

5. Jylhä V, Oikarainen A, Perälä M-L, Holopainen A. Facilitating evidencebased practice in nursing and midwifery in the WHO European Region. Copenhagen: World Health Organization, Regional Office for Europe, 2017. http://www.euro.who.int/__data/assets/pdf_file/0017/348020/ WH06_EBP_report_complete.pdf?ua=1 (accessed 29 May 2019).

6. Heikkilä A. [Research knowledge utilisation of polytechnic nursing students on graduation]. PhD Thesis, University of Turku, Finland, 2005, [Finnish]. 
7.Hendricks J, Cope V. Research is not a `scary` word: Registered nurses and the barriers to research utilization. Nord J Nurs Res. 2017; 37: 44-50

8. Belowska J, Panczyk M, Zarzeka A, Iwanow L, Cieślak I, Gotlib J. Promoting evidence-based practice - perceived knowledge, behaviours and attitudes of Polish nurses: a cross-sectional validation study. Int J Occup Saf Ergon. 2018; 27: 1-9.

9. Leach MJ, Hofmeyer A, Bobridge A. The impact of research education on student nurse attitude, skill and uptake of evidence-based practice: a descriptive longitudinal survey. J Clin Nurs. 2016; 25: 194-203.

10. Gotlib J, Belowska J, Panczyk M, Dykowska G, Wójcik GM. [Evidencebased Medicine and Evidence-based Nursing Practice - a review of the Polish scientific literature]. Problemy Pielegniarstwa 2014; 22: 223-227, [Polish].

11. Brooke J, Hvalič-Touzery S, Skela-Savič, B. Student nurse perceptions on evidence-based practice and research: an exploratory research study involving students from the University of Greenwich, England and the Faculty of Health Care Jesenice, Slovenia. Nurse Educ Today 2015; 35: e6-e11.

12. Heikkilä A, Hupli M, Katajisto J, Leino-Kilpi H. Finnish graduating nursing students' research utilization competence. J Nurs Educ Pract. 2018; 8(8): 119-127.

13. Mędrzycka-Dąbrowska W, Dąbrowski S, Gutysz-Wojnicka A, Basiński, A. Polish nurses' perceived barriers in using evidence-based practice in pain management. Int Nurs Rev. 2016; 63: 316-327.

14. Keib C, Cailor S, Kiersma M, Chen AMH. Changes in nursing students' perceptions of research and evidence-based practice after completing a research course. Nurse Educ Today. 2017; 54: 37-43.

15. Florin J, Ehrenberg A, Wallin L, Gustavsson P. Educational support for research utilisation and capability beliefs regarding evidence-based practice skills: a national survey of senior nursing students. J Adv Nurs. 2012; 68: 888-897.

16. Ryan E. Undergraduate nursing students' attitudes and use of research and evidence-based practice - an integrative literature review. J Clin Nurs. 2016; 25: 1548-1556.

17. Robertson DS, Felicilda-Reynaldo R. Evaluation of graduate nursing students' information literacy self-efficacy and applied skills. J Nurs Educ. 2015; 54: S26-S30.

18. Al Qadire M. Undergraduate student nurses' knowledge of evidencebased practice: A short online survey. Nurse Educ Today 2019; 72: 1-5.
19. Gotlib J, Belowska J, Panczyk M, Sienkiewicz Z, Wojcik G. [Knowledge and attitudes of nurses towards using study results in everyday clinical practice - preliminary report]. Problemy Pielęgniarstwa 2014; 22(2): 281-287, [Polish].

20.Zeleníková R, Beach M, Ren D, Wolff E, Sherwood P. Faculty perception of the effectiveness of EBP courses for graduate nursing students. Worldviews Evid Based Nurs 2014; 11: 401-413.

21. Lahtinen P, Leino-Kilpi H, Salminen L. Nursing education in the European higher education area - Variations in implementation. Nurse Educ Today 2014; 34: 1040-1047.

22. [The Nurses and Midwives Act]. http://prawo.sejm.gov.pl/isap.nsf/ DocDetails.xsp?id=WDU20111741039 (accessed 29 May 2019), [Polish].

23. Belowska J, Panczyk M, Zarzeka A, Gotlib, J. Knowledge and attitudes of nursing students towards evidence-based medicine and evidence-based nursing practice. Pol J Public Health. 2015; 125: 201-204.

24. Romppanen M. [Nursing students' significant nursing experiences and learning from them in a clinical learning environment]. PhD Thesis, University of Eastern Finland, Finland, 2011, [Finnish].

25. Eriksson E, Korhonen T, Merasto M, Moisio E-L. [Nurse Professional Competence - The Future of Nursing Education Project]. Ammattikorkeakoulujen terveysalan verkosto ja Suomen sairaanhoitajaliitto ry. Porvoo: Bookwell Oy, 2015, [Finnish].

26. Thorsteinsson HS. Translation and validation of two evidence-based nursing practice instruments. Int Nurs Rev. 2012; 59: 259-265.

27. DeVellis RF. Scale Development: Theory and Applications. 4th ed. Sage, 2017.

28. World Medical Association. Declaration of Helsinki: Ethical Principles for Medical Research Involving Human Subjects. JAMA 2013; 310: 2191-2194.

29. European Commission. Europeans and their Languages. Special Eurobarometer 386, 2012. http://ec.europa.eu/COMMFrontOffice/ publicopinion/index.cfm/Survey/getSurveyDetail/instruments/ SPECIAL/surveyKy/1049 (accessed 29 May 2019).

30. [Competence requirements and contents for nurses in general care $(180 \mathrm{cr}$ ) have been published]. https://blogi.savonia.fi/ylesharviointi/2019/01/31/ yleissairaanhoitajan-180-op-osaamisvaatimuslauseet-ja-sisallotjulkaistu/ (accessed 29 May 2019), [Finnish].

\title{
Postawy, wiedza i umiejętności studentów kierunku pielęgniarstwo z zakresu wykorzystania badań naukowych w praktyce pielęgniarskiej - Polska i Finlandia
}

\begin{abstract}
I Streszczenie
Wstęp. Praktyka pielęgniarska oparta na wiedzy jest niezbędna do zapewnienia pacjentom wysokiej jakości opieki. W przeprowadzonym badaniu wykorzystywanie badań naukowych jest definiowane jako proces obejmujący nabywanie umiejętności krytycznego myślenia, doboru literatury, jej ewaluacji oraz możliwości zastosowania w codziennej pracy w szpitalu.

Cel pracy. Celem pracy była ocena i porównanie wiedzy, nastawienia oraz umiejętności studentów studiów pielęgniarskich z zakresu wykorzystywania badań naukowych w pielęgniarstwie w dwóch europejskich krajach.

Materiał i metody. Badanie przeprowadzono w Polsce $(n=168)$ oraz Finladii $(n=260)$, wykorzystując do tego celu kwestionariusz Competence in Research Utilisation (CompRU).

Wyniki. Przeprowadzone analizy wykazały, że studenci zarówno z Polski, jak i Finlandii mieli pozytywne nastawienie do wykorzystywania badań naukowych w praktyce pielęgniarskiej, przy czym w przypadku studentów polskich wskaźnik ten był dużo wyższy niż w odniesieniu do studentów z Finalndii. Analiza poziomu wiedzy studentów z zakresu podstaw badań naukowych i metodologii badań naukowych wskazała na niski poziom wiedzy w każdym z badanych krajów. Ewaluacja umiejętności studentów z zakresu zastosowania wyników badań naukowych w codziennej praktyce dała wynik na poziomie średnim, przy czym studenci polscy oceniali ją na poziomie zdecydowanie wyższym w porównaniu ze studentami pochodzącymi z Finlandii.

Wnioski. Analizując uzyskane wyniki badań, widać wyraźną rozbieżność pomiędzy wiedzą studentów z zakresu metodologii badań naukowych a ich subiekty wną oceną umiejętności zastosowywania przez nich wyników badań naukowych w codziennej praktyce pielęgniarki. Nie można mówić o umiejętnościach z zakresu wykorzystywania wiedzy naukowej w sytuacji tak niskiego poziomu wiedzy studentów. Niezbędne są dalsze badania i analizy z tego zakresu.
\end{abstract}

\section{Słowa kluczowe}

pielęgniarki, postawa, wiedza, edukacja, studenci, kształcenie 